\title{
IN VITRO CONSERVATION AND ACCLIMATIZATION OF EPIDENDROIDEAE (Orchidaceae) FROM SERGIPE, BRAZIL
}

\author{
CONSERVAÇÃO IN VITRO E ACLIMATIZAÇÃO DE EPIDENDROIDEAE \\ (Orchidaceae) DE SERGIPE, BRASIL
}

\author{
Thays Saynara Alves MENEZES-SÁ ${ }^{1}$, Maria de Fátima ARRIGONI-BLANK ${ }^{2}$, \\ Andrea Santos da COSTA ${ }^{3}$, Rosana Barroso FEITOSA-ALCANTARA ${ }^{4}$, \\ Arie Fitzgerald BLANK ${ }^{2}$, José Magno Queiroz LUZ \\ 1. Doutoranda em Agricultura e Biodiversidade, UFS, São Cristóvão, SE, Brasil. thayssaynara@ yahoo.com.br; 2. Professor do \\ Departamento de Engenharia Agronômica, Universidade Federal de Sergipe, Av. Marechal Rondon s/n, São Cristóvão, SE, Brasil; \\ 3.Pós-doutoranda em Agricultura e Biodiversidade, UFS, São Cristóvão, SE, Brasil; 4. Doutora em Biotecnologia. 5. Instituto de \\ Ciências Agrárias, Universidade Federal de Uberlândia, Av. Amazonas s/n, Uberlândia-MG, Brasil.
}

\begin{abstract}
Orchids are known for the beauty, exuberance, and color of their flowers and therefore represent one of the most coveted ornamental plants. Due to their high commercial value, several illegal practices of removal and commercialization have led to the verge of extinction. This study aimed to develop protocols for in vitro conservation under slow growth and acclimatization of species of the subfamily Epidendroideae (Orchidaceae), from the state of Sergipe, Brazil. Two experiments were conducted: the first one tested four concentrations of MS (MURASHIGE and SKOOG, 1962) (25\%, 50\%, 75\%, 100\%), three orchid species (Catasetum macrocarpum, Oeceoclades maculata, and Polystachya estrellensis), and two temperatures $\left(18\right.$ and $\left.25^{\circ} \mathrm{C}\right)$; the second one tested three combinations of carbon sources and osmotic regulators (20 $\mathrm{g} \mathrm{L}^{-1}$ sucrose; $10 \mathrm{~g} \mathrm{~L}^{-1}$ sucrose $+5 \mathrm{~g} \mathrm{~L}^{-1}$ de mannitol; $10 \mathrm{~g} \mathrm{~L}^{-1}$ sucrose $+5 \mathrm{~g} \mathrm{~L}^{-1}$ sorbitol) and the same three species and two temperatures. For the in vitro conservation of $C$. macrocarpum, $O$. maculata, and $P$. estrellensis over 450 days, the use of $25 \%$ of MS salts or 20 g.. $\mathrm{L}^{-1}$ sucrose at $25^{\circ} \mathrm{C}$ is recommended. $C$. macrocarpum seedlings were acclimatized using sand + shredded pine bark + worm castings at a ratio of 2:2:1 (w:w:w). The use of sand alone is recommended for the acclimatization of $O$. maculata.
\end{abstract}

KEYWORDS: Catasetum macrocarpum; Oeceoclades maculate; Polystachya estrellensis; Slow growth; Substrate.

\section{INTRODUCTION}

The Orchidaceae family is the most diverse of all angiosperm families. It has approximately 35,000 species distributed over 1,800 genera and more than 100,000 hybrids. ROBERTS and DIXON (2008) grouped this family in five subfamilies, which are spread worldwide (MOREIRA et al., 2007), and the greatest diversity is found in the tropics (RECH et al., 2011). Orchids are ornamental plants of economic and botanical interest (CHUGH et al., 2009); they are also important for the medical, cosmetic, and food industries (GALDIANOJUNIOR et al., 2012).

The several tropical species and hybrids exhibit varied shapes, colors, and flowers, which are commercially exploited worldwide. The rapid economic development has increased the anthropic exploitation of natural resources in an exaggerated fashion. Some orchid species are endangered owing to forest devastation or the intense extractive activity by collectors and traders (COLOMBO et al., 2004), which has caused the loss of genetic material and variability in native populations. Conservation practices have increasingly relied on biotechnological applications, such as in vitro conservation.

The in vitro conservation has two procedures: slow growth, which involves reducing plant metabolism; and cryopreservation, with the complete growth suppression by storage at ultra-low temperatures. The in vitro conservation of plants allows maintaining a large number of specimens over a small footprint, without experiencing adverse weather conditions or risks associated with fieldwork (FARIA et al., 2006). This technique aims at the highest survival rate and genetic stability with the lowest frequency of subcultures.

The in vitro slow growth procedure maximizes the interval between subcultures or prolongs it indefinitely (MARCO-MEDINA and CASAS, 2012). It has been used for the conservation of several plant species, such as Vanilla planifolia (DIVAKARAN et al., 2006), Epidendrum chlorocorymbos (LOPEZ-PUC, 2013), and Paphiopedilum (NG and SALEH, 2011). This 
technique allows the storage of healthy germplasm with prolonged subculture intervals and thus reduce maintenance time and costs (SANTOS et al., 2012; PEIXOTO et al. 2017).

The acclimatization is characterized as a gradual adaptation of micropropagated plants in a greenhouse before transferring them to the field, aiming at minimizing the effects of a sudden change of environments, as they had been kept in a totally controlled and aseptic place (POSPÍSILOVÁ et al., 2007). This acclimatization consists of two stages: rooting (in vitro and ex vitro) and transfer to nonsterile conditions with controlled temperature and humidity (SILVA et al., 2003).

This process is not an easy task since microplants need to change their metabolism from heterotrophic (in vitro) to autotrophic (SILVA et al., 2003). Therefore, the choice of substrate is fundamental to the success of acclimatization. The substrate must have good physico-chemical characteristics that allow the maintenance of the root system and the gas exchange between the roots and the environment to facilitate the plant's development (FREITAS et al., 2011).

This study aimed to develop protocols for in vitro conservation under slow growth and acclimatization of species of the subfamily Epidendroideae (Orchidaceae), from the state of Sergipe, Brazil.

\section{MATERIAL AND METHODS}

The collected individuals were maintained in a greenhouse at the Department of Agronomic Engineering of the Federal University of Sergipe, Brazil. Seeds were collected in 2012 from specimens with ripe fruits and were used to establish the in vitro cultures. Catasetum macrocarpum Rich. ex Kunth., Oeceoclades maculata Lindl., and Polystachya estrellensis Rchb. f. were used in the in vitro conservation experiments, and $C$. macrocarpum and $O$. maculata were used in the acclimatization of micropropagated seedlings.

The species were established using the collected fruits. Seed capsules were washed with water and neutral detergent, disinfected in a laminar flow hood in $70 \%$ alcohol $(\mathrm{v} / \mathrm{v})$ for 1 minute and a $5 \%$ sodium hypochlorite solution for 20 minutes, and then triple-washed with autoclaved distilled water. After disinfection, capsules were opened, and seeds were isolated in Murashige and Skoog (MS) salt medium, with half the concentration of salts, plus $30 \mathrm{~g} \mathrm{~L}^{-1}$ sucrose, $7 \mathrm{~g} \mathrm{~L}^{-1}$ agar, and $1 \mathrm{~g} \mathrm{~L}^{-1}$ activated charcoal. The tubes were maintained in a biochemical oxygen demand (BOD) chamber, at a controlled temperature of $25 \pm 2^{\circ} \mathrm{C}$ and a12-hour photoperiod (luminous intensity of $60 \mu \mathrm{mol} \mathrm{m} \mathrm{m}^{-2} \mathrm{~s}^{-1}$ ). After reaching $1-2 \mathrm{~cm}$ in height, seedlings were used in the in vitro conservation and acclimatization experiments.

The in vitro conservation experiments were conducted in the Laboratory of Plant Tissue Culture and Breeding, and the acclimatization experiment was performed in a greenhouse, located in the Department of Agronomic Engineering of the Federal University of Sergipe.

All the in vitro conservation experiments used MS as the culture medium, which had the $\mathrm{pH}$ adjusted to $5.8 \pm 0.1$ before autoclaving $\left(121 \pm 1^{\circ} \mathrm{C}\right.$ and $1.05 \mathrm{~atm})$ for 15 minutes. Plants were inoculated in test tubes and maintained in a growth room, at a controlled temperature of $25 \pm 2^{\circ} \mathrm{C}$, with a 12-hour photoperiod (luminous intensity of 60 $\left.\mu \mathrm{mol} \mathrm{m} \mathrm{m}^{-1}\right)$, in a BOD chamber $\left(18^{\circ} \mathrm{C}\right)$.

\section{Reduction of MS salt medium and culture temperature}

A completely randomized experimental design was used, in a $4 \times 3 \times 2$ factorial scheme, with five replications, four MS salt medium concentrations $(25 \%, 50 \%, 75 \%$, and $100 \%)$, three species (C. macrocarpum, $O$. maculata, and $P$. estrellensis), and two temperatures $\left(18\right.$ and $\left.25^{\circ} \mathrm{C}\right)$. Each replication consisted of six tubes containing one shoot each.

\section{Osmotic regulators and culture temperature}

A completely randomized experimental design was used, in a $3 \times 3 \times 2$ factorial scheme, with five replications, to test three combinations of carbon sources and osmotic regulators $\left(20 \mathrm{~g} \mathrm{~L}^{-1}\right.$ sucrose; $10 \mathrm{~g} \mathrm{~L}^{-1}$ sucrose $+5 \mathrm{~g} \mathrm{~L}^{-1}$ mannitol; and 10 $\mathrm{g} \mathrm{L}^{-1}$ sucrose $+5 \mathrm{~g} \mathrm{~L}^{-1}$ sorbitol), three species $(C$. macrocarpum, $O$. maculata, and $P$. estrellensis), and two temperatures $\left(18\right.$ and $\left.25^{\circ} \mathrm{C}\right)$. Each replication consisted of six tubes containing one shoot each.

\section{Experiments evaluations}

For the in vitro conservation experiments, evaluations were performed after 450 days. Survival rate $(\%)$, presence of roots $(\%)$, and leaf color were evaluated, following a scoring scale, in which 5 corresponded to $100 \%$ of green leaves and shoots; 4 corresponded to the start of leaf drying; 3 corresponded to $30-50 \%$ of dead leaves; 2 corresponded to over $50 \%$ of dead leaves; and 1 corresponded to $100 \%$ of dead leaves and shoots. Plant height was evaluated according to a scoring scale (LEMOS et al., 2002), in which 4 
corresponded to a height equal to the initial height; 3 corresponded to up to the double of the initial height; 2 corresponded to heights between the double and triple of the initial height; and 1corresponded to over the triple of the initial height.

\section{Seedling acclimatization}

The seedlings acclimatization experiment used the species $C$. macrocarpum and $O$. maculata. The acclimatization of $P$. estrellensis was not possible due to the lack of available seedlings.

Seedlings established in vitro after approximately 120 days in MS medium were removed from the vials, washed in running water to eliminate any culture medium adhered to the roots, and transferred to 72 polystyrene trays containing the different treatments.

A completely randomized design was used, with five replications. The following eight substrates were tested (w/w/w): sand + worm castings $(1: 1)$; sand + coconut coir + worm castings $(2: 2: 1)$; sand + shredded pine bark + worm castings $(2: 2: 1)$; sand + shredded pine bark + coconut coir + worm castings $(2: 1: 1: 1)$; sand; sand + coconut coir $(1: 1)$; sand + shredded pine bark $(1: 1)$; and sand + shredded pine bark + coconut coir (2:1:1). Each experimental unit was composed of six seedlings. The experiment was conducted in a greenhouse with an intermittent irrigation system and covered with a $50 \%$ shade screen. Seedlings were maintained under the described treatments for 180 days. The following variables were analyzed: survival rate $(\%)$, number of leaves, height $(\mathrm{cm})$, and shoots and roots dry weight $(\mathrm{mg})$. Shoots and roots were dried in a forced-air circulation oven, at $60^{\circ} \mathrm{C}$, until constant weight, to determine shoots and roots dry weight.

\section{Statistical analysis}

Results were subject to analysis of variance (ANOVA), and when necessary, the means were compared by the Tukey's test, at the $5 \%$ probability level. For the MS medium concentration, a polynomial regression was applied, using the SISVAR software (FERREIRA, 2011). The percentage variables were transformed into the arcsine of the square root of $(\mathrm{X} / 100)$. In the acclimatization experiments, the means were compared by the Scott-Knott's test $(\mathrm{p} \leq 0.05)$.

\section{RESULTS AND DISCUSSION}

MS salt medium reduction and culture
temperature

At 450 days of in vitro conservation, the survival of the plants in response to the salt concentration and temperature were evaluated. $O$. maculata and $P$. estrellensis had the highest survival rate when maintained at $18^{\circ} \mathrm{C}$, showing values between 90 and $100 \%$ (O. maculata) and 88 and $100 \%$ ( $P$. estrellensis). At this temperature, $O$. maculated responded positively to the increase of salt concentrations in the MS medium. Conversely, $P$. estrellensis had a negative response to the increase in the salt concentration, showing a reduction in the survival rate. $C$. macrocarpum had the minimum survival rate in response to $25 \% \mathrm{MS}$ salts. (Table 1).

The evaluation of seedling survival at $25^{\circ} \mathrm{C}$ revealed that the salt concentration was significant for all the species. However, this temperature was beneficial for C. macrocarpum (97\% of survival) when compared with cultivation at $18^{\circ} \mathrm{C}$ (survival below 35\%) (Table 1). The low survival rate observed for C. macrocarpum at $18^{\circ} \mathrm{C}$ is probably because these plants are found in a coastal forest environment (restinga), where temperatures range from 25 to $35^{\circ} \mathrm{C}$, and thus, $18^{\circ} \mathrm{C}$ is below the range of tolerance for this species (MONTEIRO et al., 2012). In Cochlospermum regium (CAMILLO et al., 2009), temperatures below $20^{\circ} \mathrm{C}$ also reduced the survival rate of individuals. Temperatures below the ideal range for the cultivation of a species is one of the most commonly used strategies to induce slow growth. However, the physiological changes caused by cold temperatures may be irreversible and prevent future growth. The range of tolerance to lower or higher temperatures varies among species and even among genotypes or cultivars of the same species.

Regarding the leaf color at 450 days of in vitro conservation, the temperature of $18^{\circ} \mathrm{C}$ was favorable for $O$. maculata and $P$. estrellensis since the leaves remained completely green (score 5). For these species, the use of low temperatures possibly increased the viability of the cultures by slowing the tissue degradation process (Table 1). Low temperature has been proven efficient for reducing the growth of several species and retaining greener leaves for a longer time, as observed in Aechmea blanchetiana (SANTA-ROSA et al., 2013) and potato (ARRIGONI-BLANK et al., 2014). However, low temperatures can also be limiting for other species, as observed in this study for $C$. macrocarpum, which had scores higher than 2 , indicating over $50 \%$ of dead leaves $\left(25^{\circ} \mathrm{C}\right)$. Therefore, this species was not tolerant to lower temperatures $\left(18^{\circ} \mathrm{C}\right)$ (Table 1$)$. 
Table 1. Seedling survival (\%), leaf color (scores 1-5), and seedling height (scores 1-4) of the three species of the subfamily Epidendroideae, at 450 days of conservation, according to the species, MS salt concentration, and temperature.

\begin{tabular}{|c|c|c|c|c|c|c|}
\hline \multirow{3}{*}{$\begin{array}{l}\text { MS } \\
\text { Salts } \\
(\%) \\
\end{array}$} & \multicolumn{2}{|c|}{ Survival (\%) } & \multicolumn{2}{|c|}{ Leaf coloration (scores 1 to 5 ) } & \multicolumn{2}{|c|}{ Seedling height (scores 1 to $4^{*}$ ) } \\
\hline & \multicolumn{2}{|c|}{ Temperature } & \multicolumn{2}{|c|}{ Temperature } & \multicolumn{2}{|c|}{ Temperature } \\
\hline & $18^{\circ} \mathrm{C}$ & $25^{\circ} \mathrm{C}$ & $18^{\circ} \mathrm{C}$ & $25^{\circ} \mathrm{C}$ & $18^{\circ} \mathrm{C}$ & $25^{\circ} \mathrm{C}$ \\
\hline & \multicolumn{2}{|c|}{ C. macrocarpum } & \multicolumn{2}{|c|}{ C. macrocarpum } & \multicolumn{2}{|c|}{ C. macrocarpum } \\
\hline 25 & $23.75 \mathrm{~B}$ & $96.25 \mathrm{~A}$ & $1.66 \mathrm{~B}$ & $3.84 \mathrm{~A}$ & $3.76 \mathrm{~A}$ & $1.75 \mathrm{~B}$ \\
\hline 50 & $27.50 \mathrm{~B}$ & $96.25 \mathrm{~A}$ & $1.03 \mathrm{~B}$ & $3.66 \mathrm{~A}$ & $3.71 \mathrm{~A}$ & $1.66 \mathrm{~B}$ \\
\hline 75 & $42.50 \mathrm{~B}$ & $96.25 \mathrm{~A}$ & $1.09 \mathrm{~B}$ & $3.65 \mathrm{~A}$ & $3.57 \mathrm{~A}$ & $1.66 \mathrm{~B}$ \\
\hline 100 & $48.75 \mathrm{~B}$ & $100.00 \mathrm{~A}$ & $1.02 \mathrm{~B}$ & $2.65 \mathrm{~A}$ & $3.51 \mathrm{~A}$ & $1.67 \mathrm{~B}$ \\
\hline $\begin{array}{l}\text { Equation } \\
(\mathrm{Y})=\end{array}$ & $\begin{array}{c}13.1250+0.3600 \\
R^{2}=94.95 \%\end{array}$ & $\begin{array}{c}\mathrm{x} .3750+0.060 \mathrm{x} \\
\mathrm{R}^{2}=80.00 \%\end{array}$ & $\begin{array}{c}2.368- \\
0.0354 \mathrm{x}+0.0002 \mathrm{x}^{2} \\
\mathrm{R}^{2}=88.71 \%\end{array}$ & $\begin{array}{c}4.345-0.0143 x \\
R^{2}=73.17 \%\end{array}$ & $\begin{array}{c}3.8610-0.0035 x \\
R^{2}=96.37 \%\end{array}$ & $\begin{array}{c}1.8700- \\
0.005880 \mathrm{x}+0.00004 \mathrm{x}^{2} \\
\mathrm{R}^{2}=93.89 \%\end{array}$ \\
\hline
\end{tabular}

\begin{tabular}{|c|c|c|c|c|c|c|}
\hline \multirow[t]{2}{*}{$\mathrm{CV}(\%)$} & \multicolumn{2}{|c|}{8,74} & \multicolumn{2}{|l|}{18.32} & 2.63 & \\
\hline & \multicolumn{2}{|c|}{ O. maculata } & \multicolumn{2}{|c|}{ O. maculata } & \multicolumn{2}{|c|}{ O. maculata } \\
\hline 25 & $90.00 \mathrm{~B}$ & $100.00 \mathrm{~A}$ & $4.96 \mathrm{~A}$ & $4.00 \mathrm{~B}$ & $3.20 \mathrm{~A}$ & $3.10 \mathrm{~A}$ \\
\hline 50 & $93.33 \mathrm{~B}$ & $100.00 \mathrm{~A}$ & $4.93 \mathrm{~A}$ & $4.00 \mathrm{~B}$ & $3.20 \mathrm{~A}$ & $3.10 \mathrm{~A}$ \\
\hline 75 & $100.00 \mathrm{~A}$ & $100.00 \mathrm{~A}$ & $4.90 \mathrm{~A}$ & $4.00 \mathrm{~B}$ & $3.13 \mathrm{~A}$ & $2.80 \mathrm{~B}$ \\
\hline 100 & $100.00 \mathrm{~A}$ & $100.00 \mathrm{~B}$ & $4.80 \mathrm{~A}$ & $4.00 \mathrm{~B}$ & $3.20 \mathrm{~A}$ & $2.73 \mathrm{~B}$ \\
\hline $\begin{array}{l}\text { Equation } \\
(\mathrm{Y})=\end{array}$ & ns & ns & $\begin{array}{c}5.0333-0.0021 \mathrm{x} \\
\mathrm{R}^{2}=91.43 \%\end{array}$ & ns & $\begin{array}{c}3.2833- \\
0.0036 \mathrm{x}+0.00002 \mathrm{x}^{2} \\
\mathrm{R}^{2}=40.00 \%\end{array}$ & $\begin{array}{c}3.2833-0.0056 x \\
R^{2}=86.47 \%\end{array}$ \\
\hline
\end{tabular}

\begin{tabular}{|c|c|c|c|c|c|c|}
\hline \multirow[t]{2}{*}{$\overline{\mathrm{CV}(\%)}$} & \multicolumn{2}{|c|}{5.44} & \multicolumn{2}{|l|}{1.36} & \multicolumn{2}{|l|}{4.35} \\
\hline & \multicolumn{2}{|c|}{ P. estrellensis } & \multicolumn{2}{|c|}{ P. estrellensis } & \multicolumn{2}{|c|}{ P. estrellensis } \\
\hline 25 & $100.00 \mathrm{~A}$ & $100.00 \mathrm{~A}$ & $4.46 \mathrm{~A}$ & $3.60 \mathrm{~B}$ & $3.06 \mathrm{~A}$ & $2.13 \mathrm{~B}$ \\
\hline 50 & $100.00 \mathrm{~A}$ & $100.00 \mathrm{~A}$ & $4.46 \mathrm{~A}$ & $3.76 \mathrm{~B}$ & $3.10 \mathrm{~A}$ & $2.10 \mathrm{~B}$ \\
\hline 75 & $96.66 \mathrm{~A}$ & $96.66 \mathrm{~A}$ & $4.63 \mathrm{~A}$ & $3.83 \mathrm{~B}$ & $3.03 \mathrm{~A}$ & $2.10 \mathrm{~B}$ \\
\hline 100 & $88.00 \mathrm{~A}$ & $96.66 \mathrm{~A}$ & $4.60 \mathrm{~A}$ & $3.80 \mathrm{~B}$ & $3.00 \mathrm{~A}$ & $2.10 \mathrm{~B}$ \\
\hline
\end{tabular}

\begin{tabular}{|c|c|c|c|c|c|c|}
\hline $\begin{array}{l}\text { Equation } \\
(\mathrm{Y})=\end{array}$ & ns & ns & ns & $\mathrm{ns}$ & ns & ns \\
\hline $\mathrm{CV}(\%)$ & & & & & & \\
\hline
\end{tabular}

Means followed by the same uppercase letters between temperatures do not statistically differ by the Tukey's test at the 5\% probability level. CV - coefficient of variation. Color scores: $5=$ completely green leaves and shoots; $4=$ beginning of leaf drying; $3=30-50 \%$ dead leaves; 2 = over $50 \%$ dead leaves; and $1=$ completely dead leaves and shoots. Height scores: $4=$ height similar to initial height $(1-2$ $\mathrm{cm}) ; 3=$ up to the double of the initial height; $2=$ between the double and triple of the initial height; and $1=$ over the triple of the initial height.

O. maculata and $P$. estrellensis plants maintained at $25^{\circ} \mathrm{C}$ had scores of approximately 4 , indicating the beginning of leaf drying. This temperature was only better than $18^{\circ} \mathrm{C}$ for $C$. macrocarpum, following the same survival trend (Table 1). Plants with high color scores (greener) should be chosen because senescence is not acceptable for slow growth conservation. Moreover, plants must remain viable for future growth (SANTOS et al., 2012).

The analysis of seedling height at 450 days of cultivation revealed the minimal growth for $C$. macrocarpum at $18^{\circ} \mathrm{C}$. This species showed the lowest scores when compared with the other species at all concentrations of MS salts. However, under this temperature, only $35 \%$ of C. macrocarpum plants survived (Table 1). When maintained at $25^{\circ} \mathrm{C}$, this species showed greater growth than the others
(Table 1). In general, $25^{\circ} \mathrm{C}$ resulted in greater seedling growth, except for $O$. maculata seedlings, which exhibited lower growth using 25 to $100 \%$ salts at $18^{\circ} \mathrm{C}$ (Table 1). Similar behavior was observed in A. blanchetiana, which maintained the lowest growth indices at 360 days at lower temperatures (SANTA-ROSA et al., 2013).

When performing in vitro conservation, plant height is an important variable to indicate the subculturing time because when the medium is exhausted, the plant growth is affected by the lack of nutrients. At this point, the number of senescent leaves increases, indicating a weak physiological state and the need to change the medium.

\section{Osmotic regulators and culture temperature}

Seedling survival rates throughout 450 days of conservation under slow growth were between 80 and $100 \%$ for all species, regardless of the culture 
temperature, except for $C$. macrocarpum at the temperature of $18^{\circ} \mathrm{C}$, whose survival rate of microcultures reduced. A mean survival rate of $25 \%$ (Table 2) indicates that the temperature of $18^{\circ} \mathrm{C}$ should not be used in slow growth conservation for that species. No significant differences were observed between osmotic regulators in the analysis of the survival rate at $25^{\circ} \mathrm{C}$, and the values ranged from 88 to $100 \%$ (Table 2). A higher survival rate was detected for $C$. macrocarpum seedlings at this temperature when compared with the survival rate at $18^{\circ} \mathrm{C}$ (Table 2). Similar results were found in Agave nizandensis, which was in vitro-conserved for 300 days, with sucrose:mannitol:sorbitol (30:50:50 $\mathrm{g} \mathrm{L}^{-}$ $\left.{ }^{1}\right)$, at $25^{\circ} \mathrm{C}$ (BALCH et al., 2012).

Table 2. Seedling survival (\%), leaf color (scores 1-5), and seedling height (scores 1-4) of three species of the subfamily Epidendroideae, at 450 days of conservation, in function of species, osmotic regulators, and temperature.

\begin{tabular}{|c|c|c|c|}
\hline \multirow{2}{*}{ Osmotic Regulators $\left(\mathrm{g} \mathrm{L}^{-1}\right)$} & \multicolumn{3}{|c|}{ Species } \\
\hline & C. macrocarpum & O. maculata & P. estrellensis \\
\hline & \multicolumn{3}{|c|}{ Survival } \\
\hline & \multicolumn{3}{|c|}{ 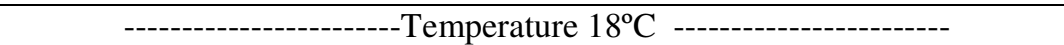 } \\
\hline Sucrose (20) & $23.75 \mathrm{a} ß$ & $100.00 \mathrm{a} \alpha$ & $92.00 \mathrm{a} \alpha$ \\
\hline Sucrose + Mannitol (10:5) & $21.25 \mathrm{a} ß$ & $84.00 \mathrm{bß}$ & $92.00 \mathrm{a} \alpha$ \\
\hline \multirow[t]{2}{*}{ Sucrose + Sorbitol (10:5) } & $28.75 \mathrm{a} ß$ & $84.00 \mathrm{~b} ß$ & $88.00 \mathrm{a} \alpha$ \\
\hline & \multicolumn{3}{|c|}{----------------------Temperature $25^{\circ} \mathrm{C}$} \\
\hline Sucrose (20) & $98.75 \mathrm{a} \alpha$ & $100.00 \mathrm{a} \alpha$ & $96.00 \mathrm{a} \alpha$ \\
\hline Sucrose + Mannitol (10:5) & $96.25 \mathrm{a} \alpha$ & $100.00 \mathrm{a} \alpha$ & $92.00 \mathrm{a} \alpha$ \\
\hline Sucrose + Sorbitol (10:5) & $93.75 \mathrm{a} \alpha$ & $100.00 \mathrm{a} \alpha$ & $88.00 \mathrm{a} \alpha$ \\
\hline \multirow[t]{2}{*}{$\mathrm{CV}(\%)$} & \multicolumn{3}{|c|}{11.33} \\
\hline & \multicolumn{3}{|c|}{ Leaf color } \\
\hline Sucrose (20) & $1.89 \mathrm{aß}$ & $4.36 \mathrm{a} \alpha$ & $4.00 \mathrm{a} \alpha$ \\
\hline Sucrose + Mannitol (10:5) & $1.80 \mathrm{a} ß$ & $4.63 \mathrm{a} \alpha$ & $3.80 \mathrm{a} \alpha$ \\
\hline \multirow[t]{2}{*}{ Sucrose + Sorbitol (10:5) } & $1.84 \mathrm{a} ß$ & $4.36 \mathrm{a} \alpha$ & $3.70 \mathrm{a} \alpha$ \\
\hline & \multicolumn{3}{|c|}{-----------Temperature $25^{\circ} \mathrm{C}$} \\
\hline Sucrose (20) & $3.92 \mathrm{a} \alpha$ & $3.96 \mathrm{a} \alpha$ & $3.43 \mathrm{a} \alpha$ \\
\hline Sucrose + Mannitol (10:5) & $3.98 \mathrm{a} \alpha$ & $3.90 \mathrm{a} \alpha$ & $3.30 \mathrm{a} \alpha$ \\
\hline Sucrose + Sorbitol (10:5) & $3.82 \mathrm{a} \alpha$ & $3.90 \mathrm{a} \alpha$ & $3.10 \mathrm{a} \alpha$ \\
\hline \multirow[t]{2}{*}{$\mathrm{CV}(\%)$} & \multicolumn{3}{|c|}{9.13} \\
\hline & \multicolumn{3}{|c|}{ Seedling height } \\
\hline Sucrose (20) & $3.24 \mathrm{a} \alpha$ & $2.86 \mathrm{a} \alpha$ & $2.90 \mathrm{a} \alpha$ \\
\hline Sucrose + Mannitol (10:5) & $3.63 \mathrm{a} \alpha$ & $3.00 \mathrm{a} \alpha$ & $2.93 \mathrm{a} \alpha$ \\
\hline \multirow[t]{2}{*}{ Sucrose + Sorbitol (10:5) } & $3.65 \mathrm{a} \alpha$ & $3.00 \mathrm{a} \alpha$ & $3.00 \mathrm{a} \alpha$ \\
\hline & \multicolumn{3}{|c|}{ - $25^{\circ} \mathrm{C}$} \\
\hline Sucrose (20) & $2.98 \mathrm{a} \alpha$ & $2.40 \mathrm{a} \alpha$ & $2.03 \mathrm{a} \beta$ \\
\hline Sucrose + Mannitol (10:5) & $3.04 \mathrm{a}$ & $2.86 \mathrm{a} \alpha$ & $2.10 \mathrm{a} \beta$ \\
\hline Sucrose + Sorbitol (10:5) & $3.03 \mathrm{aß}$ & $2.80 \mathrm{a} \alpha$ & $2.20 \mathrm{a} \beta$ \\
\hline $\mathrm{CV}(\%)$ & \multicolumn{3}{|c|}{9.94} \\
\hline
\end{tabular}

Means followed by the same lowercase letters in the same column and Greek letters between temperatures do not differ statistically by the Tukey's test at 5\% probability. Color scores: $5=$ completely green leaves and shoots; $4=$ beginning of leaf drying; $3=30-50 \%$ dead leaves; $2=$ over $50 \%$ dead leaves; and $1=$ completely dead leaves and shoots. Height scores: $4=$ height similar to the initial height (1-2 $\mathrm{cm}$ ); $3=$ up to the double of the initial height; $2=$ between the double and triple of the initial height; and $1=$ over the triple of the initial height. CV - coefficient of variation.

Regarding the color, $P$. estrellensis and $O$. maculata had the highest scores at the temperature of $18^{\circ} \mathrm{C}$. The latter species showed the highest mean (4.45), indicating the beginning of leaf drying, regardless of the osmotic regulator. This same temperature was not favorable for color maintenance in $C$. macrocarpum because this species had approximately completely dead leaves and shoots (score 1) at 450 days of conservation (Table 2). Leaf color at $25^{\circ} \mathrm{C}$ had a greater uniformity of scores (3.10-3.98), with scores closer to 3 , which indicates between 30 and $50 \%$ of dead leaves (Table 2). When comparing the two temperatures, $18^{\circ} \mathrm{C}$ enabled seedlings to maintain greener leaves, possibly due to the slower metabolism, although the temperature of $25^{\circ} \mathrm{C}$ was 
the most favorable for C. macrocarpum. A. fasciata also had greener leaves when conserved at $25^{\circ} \mathrm{C}$ for 360 days (COSTA et al., 2012).

The analysis of seedling height at 450 days of cultivation at the temperature of $18^{\circ} \mathrm{C}$ revealed that the combination of sucrose with mannitol and sorbitol led to the high scores for $C$. macrocarpum (3.6, up to the double of the initial height) and $P$. estrellensis and $O$. maculata (between the double and triple of the initial height) (Table 2). The analysis of temperatures indicated that $25^{\circ} \mathrm{C}$ was favorable to greater seedling heights, regardless of the osmotic regulator (Table 2). After 450 days of in vitro conservation of $C$. macrocarpum, $O$. maculata, and $P$. estrellensis, the explants originated from all the treatments reestablished their growth when placed in normal in vitro cultivation.

For in vitro conservation, slow plant growth is important for avoiding successive subcultures and preserving the plant's capacity to recover and multiply. A viability analysis is required to certify the successful development of a conservation protocol. Therefore, the three species of orchid microplants were placed in the MS medium for the evaluation of their development. The viability analysis showed that the concentrations of MS salts and osmotic regulators used in the conservation protocol did not hinder the responsive capacity of the culture. Thus, the plants maintained high vigor and development, even after months without changing the culture medium.

\section{Seedling acclimatization}

The ANOVA test showed significant differences for substrate mixtures after 180 days of acclimatization. For $C$. macrocarpum, the comparison between substrates revealed mean survival rates ranging from $50 \%$ to $100 \%$ (Table 3 ). The best results were obtained in mixtures that contained worm castings (90-100\% survival) (Table 3 ). Worm castings might have contributed to the development of seedlings since it is an organic material rich in nutrients (nitrogen, phosphorous, potassium, magnesium, calcium, and several micronutrients). Therefore, this substrate favors the seedlings survival over the cultivation (KNAPIK and ANGELO 2007).

The different mixtures of substrates did not influence the survival rate of $O$. maculata during the acclimatization experiment since the values ranged from 83 to $100 \%$ (Table 3). These values were probably the result of the ability of this species to adapt to different environments, from sandy to rainforests soils. Owing to its adaptation and environmental colonization, this species is considered as a bioindicator orchid for anthropic forest fragments (DUBBERN et al., 2013).

The analysis of plant height for $C$. macrocarpum showed that the substrate mixture sand + shredded pine bark + coconut coir + worm castings $(2: 1: 1: 1)$ resulted in the tallest plants $(5.8$ $\mathrm{cm}$ ) (Table 3). Similar results were obtained in the acclimatization of Cattleya guttata $x$ Laelia tenebrosa, using mixtures containing coconut coir and fiber (COLOMBO et al., 2005). For $O$. maculata, the use of sand and worm castings (1:1) led to the greatest plant growth $(6.51 \mathrm{~cm})$ (Table 3).

C. macrocarpum reached the largest number of leaves per plant when using the mixtures containing sand + worm castings (1:1) and sand + shredded pine bark + worm castings (2:2:1). Conversely, $O$. maculata reached the smallest number of leaves per plant when using sand + worm castings $(1: 1)$ and sand + coconut coir + worm castings (2:2:1) (Table 3$)$. The combination of worm castings with coconut coir also led to an increase in the number of $O$. maculata leaves during acclimatization (ROCHA et al., 2009). Seedlings with a larger number of leaves have higher survival rates in the field since leaves are responsible for capturing solar energy to produce organic material through photosynthesis (ASSIS et al., 2009).

The analysis of the shoot dry weight of $C$. macrocarpum revealed that the lowest values were obtained in the mixtures of substrates that did not contain worm castings [sand; sand + coconut coir $(1: 1)$; sand + shredded pine bark (1:1); sand + shredded pine bark + coconut coir (2:1:1)], with values between 4.5 and $11.3 \mathrm{mg}$. However, the highest values of shoot dry weight $(43.4 \mathrm{mg})$ was provided by the mixture of sand + shredded pine bark + worm castings $(2: 2: 1)$. This fact might have been the result of the improved nutritional aspects of the substrates containing worm castings and the presence of sand and shredded pine bark, which offer better physical properties and adequate water supply (Table 3). 
Table 3. Survival rate (\%), plant height, number of leaves, and shoots and roots dry weight (mg) of Catasetum macrocarpum and Oeceoclades maculata, in function of different substrate mixtures, at 180 days of cultivation.

\begin{tabular}{|c|c|c|}
\hline Substrates & C. macrocarpum & O. maculata \\
\hline & \multicolumn{2}{|c|}{-------------------- Survival (\%) -------------------- } \\
\hline $\mathrm{S}: \mathrm{WC}(1: 1)$ & $90.0 \mathrm{a}$ & $83.3 \mathrm{a}$ \\
\hline $\mathrm{S}: \mathrm{CC}: \mathrm{WC}(2: 2: 1)$ & $100.0 \mathrm{a}$ & $96.7 \mathrm{a}$ \\
\hline S:SPB:WC (2:2:1) & $100.0 \mathrm{a}$ & $96.7 \mathrm{a}$ \\
\hline S:SPB:CC:WC (2:1:1:1) & $90.0 \mathrm{a}$ & $100.0 \mathrm{a}$ \\
\hline $\mathrm{S}$ & $76.7 \mathrm{~b}$ & $100.0 \mathrm{a}$ \\
\hline $\mathrm{S}: \mathrm{CC}(1: 1)$ & $80.0 \mathrm{~b}$ & $90.0 \mathrm{a}$ \\
\hline S:SPB $(1: 1)$ & $53.3 \mathrm{c}$ & $100.0 \mathrm{a}$ \\
\hline $\mathrm{S}: \mathrm{SPB}: \mathrm{CC}(2: 1: 1)$ & $50.0 \mathrm{c}$ & $100.0 \mathrm{a}$ \\
\hline \multirow[t]{2}{*}{$\mathrm{CV}(\%)$} & \multicolumn{2}{|c|}{14.54} \\
\hline & \multicolumn{2}{|c|}{ |------------------- Plant height (cm) -------------------- } \\
\hline $\mathrm{S}: \mathrm{WC}(1: 1)$ & $4.0 \mathrm{c}$ & $6.5 \mathrm{a}$ \\
\hline $\mathrm{S}: \mathrm{CC}: \mathrm{WC}(2: 2: 1)$ & $3.9 \mathrm{c}$ & $5.9 \mathrm{~b}$ \\
\hline S:SPB:WC (2:2:1) & $5.2 \mathrm{~b}$ & $5.2 \mathrm{c}$ \\
\hline S:SPB:CC:WC (2:1:1:1) & $5.8 \mathrm{a}$ & $5.0 \mathrm{c}$ \\
\hline $\mathrm{S}$ & $3.6 \mathrm{~d}$ & $4.7 \mathrm{c}$ \\
\hline $\mathrm{S}: \mathrm{CC}(1: 1)$ & $3.3 \mathrm{~d}$ & $4.2 \mathrm{~d}$ \\
\hline S:SPB $(1: 1)$ & $3.3 \mathrm{~d}$ & $2.8 \mathrm{e}$ \\
\hline $\mathrm{S}: \mathrm{SPB}: \mathrm{CC}(2: 1: 1)$ & $3.2 \mathrm{~d}$ & $2.6 \mathrm{e}$ \\
\hline \multirow[t]{2}{*}{$\mathrm{CV}(\%)$} & \multicolumn{2}{|c|}{8.88} \\
\hline & \multicolumn{2}{|c|}{------------------- Number of leaves ------------------- } \\
\hline $\mathrm{S}: \mathrm{WC}(1: 1)$ & $6.8 \mathrm{a}$ & $2.8 \mathrm{~b}$ \\
\hline $\mathrm{S}: \mathrm{CC}: \mathrm{WC}(2: 2: 1)$ & $5.7 \mathrm{~b}$ & $3.3 \mathrm{~b}$ \\
\hline S:SPB:WC (2:2:1) & $6.3 \mathrm{a}$ & $4.3 \mathrm{a}$ \\
\hline S:SPB:CC:WC (2:1:1:1) & $5.5 \mathrm{~b}$ & $4.3 \mathrm{a}$ \\
\hline $\mathrm{S}$ & $4.2 \mathrm{c}$ & $4.4 \mathrm{a}$ \\
\hline $\mathrm{S}: \mathrm{CC}(1: 1)$ & $4.1 \mathrm{c}$ & $4.2 \mathrm{a}$ \\
\hline S:SPB (1:1) & $4.4 \mathrm{c}$ & $3.7 \mathrm{a}$ \\
\hline S:SPB:CC (2:1:1) & $3.5 \mathrm{c}$ & $3.9 \mathrm{a}$ \\
\hline \multirow[t]{2}{*}{$\mathrm{CV}(\%)$} & \multicolumn{2}{|c|}{16.78} \\
\hline & \multicolumn{2}{|c|}{--------------- Shoots dry weight (mg) -------------- } \\
\hline $\mathrm{S}: \mathrm{WC}(1: 1)$ & $28.5 \mathrm{~b}$ & $16.6 \mathrm{~b}$ \\
\hline $\mathrm{S}: \mathrm{CC}: \mathrm{WC}(2: 2: 1)$ & $20.8 \mathrm{~b}$ & $23.5 \mathrm{~b}$ \\
\hline S:SPB:WC (2:2:1) & $43.4 \mathrm{a}$ & $33.5 \mathrm{a}$ \\
\hline S:SPB:CC:WC (2:1:1:1) & $24.2 \mathrm{~b}$ & $34.7 \mathrm{a}$ \\
\hline $\mathrm{S}$ & $4.5 \mathrm{c}$ & $33.8 \mathrm{a}$ \\
\hline $\mathrm{S}: \mathrm{CC}(1: 1)$ & $11.3 \mathrm{c}$ & $38.6 \mathrm{a}$ \\
\hline $\mathrm{S}: \mathrm{SPB}(1: 1)$ & $10.5 \mathrm{c}$ & $14.4 \mathrm{~b}$ \\
\hline S:SPB:CC $(2: 1: 1)$ & $9.2 \mathrm{c}$ & $18.4 \mathrm{~b}$ \\
\hline \multirow[t]{2}{*}{$\mathrm{CV}(\%)$} & \multicolumn{2}{|c|}{34.38} \\
\hline & \multicolumn{2}{|c|}{ - } \\
\hline $\mathrm{S}: \mathrm{WC}(1: 1)$ & $34.7 \mathrm{a}$ & $11.2 \mathrm{c}$ \\
\hline $\mathrm{S}: \mathrm{CC}: \mathrm{WC}(2: 2: 1)$ & $18.9 \mathrm{~b}$ & $16.6 \mathrm{c}$ \\
\hline S:SPB:WC (2:2:1) & $39.7 \mathrm{a}$ & $24.0 \mathrm{~b}$ \\
\hline S:SPB:CC:WC (2:1:1:1) & $32.2 \mathrm{a}$ & $27.4 \mathrm{~b}$ \\
\hline $\mathrm{S}$ & $9.0 \mathrm{~b}$ & $45.4 \mathrm{a}$ \\
\hline $\mathrm{S}: \mathrm{CC}(1: 1)$ & $14.4 \mathrm{~b}$ & $24.0 \mathrm{~b}$ \\
\hline S:SPB (1:1) & $27.6 \mathrm{a}$ & $13.1 \mathrm{c}$ \\
\hline $\mathrm{S}: \mathrm{SPB}: \mathrm{CC}(2: 1: 1)$ & $19.1 \mathrm{~b}$ & $14.9 \mathrm{c}$ \\
\hline $\mathrm{CV}(\%)$ & & \\
\hline \multicolumn{3}{|c|}{ 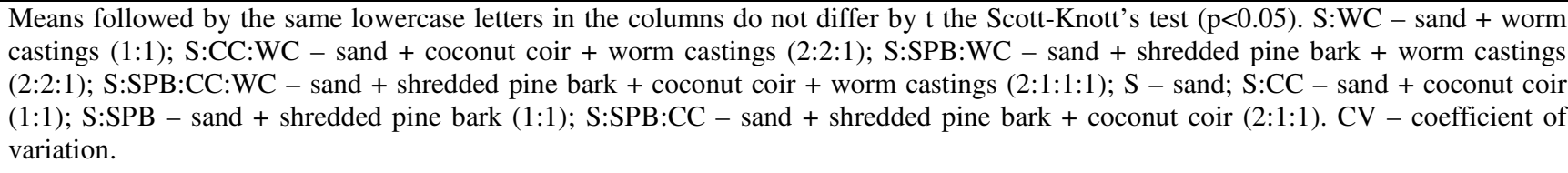 } \\
\hline
\end{tabular}


In general, higher values were observed for $O$. maculata, and the substrates sand + shredded pine bark + worm castings $(2: 2: 1)$, sand + shredded pine bark + coconut coir + worm castings $(2: 1: 1: 1)$, sand, and sand + coconut coir (1:1) provided the highest values (Table 3). Similar results were reported for the acclimatization of Phalaenopsis ssp. using mixtures containing pine bark, which enabled greater dry weight accumulation and might have promoted greater moisture retention (AMARAL et al., 2010).

Considering the variable root dry weight in C. macrocarpum, a higher value was provided by the substrates sand + worm castings (1:1), sand + shredded pine bark + worm castings $(2: 2: 1)$, sand + shredded pine bark + coconut coir + worm castings (2:1:1:1), and sand + shredded pine bark (1:1), with a mean of $33.58 \mathrm{mg}$ of biomass. For $O$. maculata, however, the highest biomass was obtained with the substrate sand $(45.46 \mathrm{mg}$ ) (Table 3). Generally, the mixtures of coconut coir, sand, and pine bark favored moisture retention and aeration, improved the physical conditions of the plants, and enabled the root development and growth (AMARAL et al., 2010), which corroborated the results obtained for C. macrocarpum. Nevertheless, the highest root dry weight for $O$. maculata was obtained when using sand. This result probably occurred because $O$. maculata is a terrestrial orchid commonly found in sandy environments. O. maculata is indicated as an invasive species in disturbed environments, which assists in the diagnosis of interference in forest fragments (DUBBERN et al., 2013) and (UENO, 2013).

\section{CONCLUSIONS}

For the in vitro conservation of $C$. macrocarpum, $O$. maculata, and $P$. estrellensis throughout 450 days, $25 \% \mathrm{MS}$ salts at a temperature of $25^{\circ} \mathrm{C}$, or $20 \mathrm{~g} \mathrm{~L}^{-1}$ sucrose at $25^{\circ} \mathrm{C}$ should be used.

For the acclimatization of $C$. macrocarpum seedlings for 180 days, the substrate composed of sand + shredded pine bark + worm castings $(2: 2: 1)$ is recommended. Conversely, for the acclimatization of $O$. maculata seedlings at 180 days, the exclusive use of sand is enough.

\section{ACKNOWLEDGMENTS}

This study was financed, in part, by the Conselho Conselho Nacional de Desenvolvimento Científico e Tecnológico - Brasil (CNPq), the Fundação de Apoio à Pesquisa e a Inovação Tecnológica do Estado de Sergipe (Fapitec/SE) Brasil, the Coordenação de Aperfeiçoamento de Pessoal de Nível Superior - Brasil (CAPES Finance Code 001), and the Financiadora de Estudos e Projetos - Brasil (FINEP).

RESUMO: As orquídeas são conhecidas pela beleza, exuberância e cores de suas flores e por isso representam uma das plantas ornamentais mais cobiçadas. Devido ao alto valor comercial, muitas são as práticas ilegais de retirada e comercialização de orquídeas, o que leva as espécies à beira de extinção. $\mathrm{O}$ objetivo deste estudo foi desenvolver protocolos para a conservação in vitro sob crescimento lento e aclimatação de espécies da subfamília Epidendroideae (Orchidaceae) do Estado de Sergipe, Brasil. Dois experimentos foram realizados: o primeiro ensaio testou quatro concentrações dos sais MS (MURASHIGE e SKOOG, 1962) (25, 50, 75 e 100\%), três espécies (Catasetum macrocarpum, Oeceoclades maculata e Polystachya estrellensis) e duas temperaturas $\left(18\right.$ e $\left.25^{\circ} \mathrm{C}\right)$; o segundo ensaio testou três combinações de fontes de carbono e reguladores osmóticos $\left(20 \mathrm{~g} \mathrm{~L}^{-1}\right.$ de sacarose; $10 \mathrm{~g} \mathrm{~L}^{-1}$ de sacarose $+5 \mathrm{~g} \mathrm{~L}^{-1}$ manitol; $10 \mathrm{~g} \mathrm{~L}^{-1}$ de sacarose $+5 \mathrm{~g} \mathrm{~L}^{-1}$ sorbitol), três espécies (C. macrocarpum, $O$. maculata e P. estrellensis) e duas temperaturas $\left(18\right.$ e $\left.25^{\circ} \mathrm{C}\right)$. Para executar a aclimatação, oito substratos foram testados para as espécies $C$. macrocarpum e $O$. maculata. Para realizar a conservação in vitro de $C$. macrocarpum, $O$. maculata e $P$. estrellensis ao longo de 450 dias, recomenda-se a utilização $25 \%$ dos sais de MS e de $20 \mathrm{~g} \mathrm{~L}^{-1}$ de sacarose a $25^{\circ} \mathrm{C}$. Mudas de $C$. macrocarpum foram aclimatizadas utilizando areia + casca de pinus + húmus de minhoca (2:2:1). Recomendase a utilização de areia para aclimatização de $O$. maculata.

PALAVRA-CHAVE: Catasetum macrocarpum. Oeceoclades maculata. Polystachya estrellensis. Crescimento lento. Substrato 


\section{REFERENCES}

AMARAL, T. L.; JASMIM, J. M.; ARAÚJO, J. S. P.; THIÉBAUT, J. T. L.; COELHO, F. C.; FREITAS, C. B. Adubação de orquídeas em substratos com fibra de coco. Ciência e Agrotecnologia, v. 34, n. 1, p. 11-19, 2010. http://dx.doi.org/10.1590/S141370542010000100001

ARRIGONI-BLANK, M. F.; TAVARES, F. F.; BLANK, A. F.; SANTOS, M. C.; MENEZES, T. S. A. SANTANA, A. D. D. In vitro conservation of sweet potato genotypes. The Scientific World Journal, v. 2014, n. 1, p. 1-7, 2014. http://dx.doi.org/10.1155/2014/208506

ASSIS, A. M.; FARIA, R. T.; UNEMATO, L. K.; COLOMBO, L. A.; LONE, A.B. Aclimatização de bastãodo-imperador (Etlingera elatior) em substratos à base de coco. Acta Scientiarum Agronomy, v. 31, n. 1, p. 43-47, 2009. http://dx.doi.org/10.4025/actasciagron.v31i1.6621

BALCH, E. P. M.; ARAIZA, M. J. E.; REYES, M. E.P. (2012) In vitro Conservation of agave spp. germplasm under slow growth conditions. Revista Fitotecnia Mexicana, v. 35, n. 4, p. 279-287, 2012.

http://dx.doi.org/10. 0187-73802012000400004

CAMILLO, J.; SCHERWINSKI-PEREIRA, J. E.; VIEIRA, R. F.; PEIXOTO, J. R. Conservação in vitro de Cochlospermum regium (Schrank) Pilg. - Cochlospermaceae sob regime de crescimento mínimo. Revista Brasileira de Plantas Medicinais, v. 11, n. 2, p. 184-189, 2009. http://dx.doi.org/10.1590/S151605722009000200012

CHUGH, S.; GUHA, S.; RAO, I. U. Micropropagation of orchids: a review on the potential of different explants. Scientia Horticulturae, v. 122, n. 4, p. 507-520, 2009.

http://dx.doi.org/10.1016/j.scienta.2009.07.016

COLOMBO, L. A.; FARIA, R. T.; CARVALHO, J. F. R. P.; ASSIS, A. M.; FONSECA, I. C. B. Influência do fungicida clorotalonil no desenvolvimento vegetativo e no enraizamento in vitro de duas espécies de orquídeas brasileiras. Acta Scientiarum Agronomy, v. 26, n. 2, p. 253-258, 2004.

http://dx.doi.org/10.4025/actasciagron.v26i2.1893

COLOMBO, L. A.; FARIA, R. T.; ASSIS, A. M.; FONSECA, I. C. B. Aclimatização de um híbrido de Cattleya em substratos de origem vegetal sob dois sistemas de irrigação. Acta Scientiarum Agronomy, v. 27, n. 1, p. 145-150, 2005. http://dx.doi.org/10.4025/actasciagron.v27i1.2134

COSTA, M. A. P. C.; MOREIRA, M. J. S.; SOUZA, F.V. D.; ROCHA, M. A. C. Conservação in vitro de Aechmea fasciata (Lindley) Baker e Aechmea miniata Beer ex Baker (Bromeliaceae-Bromelioideae).

Magistra, v. 24, n. 4, p. 293-303, 2012. http://dx.doi.org/10. BR2013007961

DIVAKARAN, M; BABU, K. N.; PETER, K.V. Conservation of Vanilla species, in vitro. Scientia Horticulturae, v. 110, n. 1, p. 175-180, 2006. https://doi.org/10.1016/j.scienta.2006.07.003

DUBBERN, C. A.; LEAL, T. S.; MORAES, C. P. Distribuição espacial de Oeceoclades maculata Lindl. (Orchidaceae) em fragmento florestal Estacional Semidecidual da fazenda Santa Tereza, Cordeirópolis, SP, Brasil. Natureza on line, v. 11, n. 1, p. 29-32, 2013. http://dx.doi.org/10.263276170

FARIA, G. A.; COSTA, M. A. P. C.; JUNGHANS, T. G.; LÉDO, C. A.S.; SOUZA, A.S. Efeito da sacarose e sorbitol na conservação in vitro de Passiflora giberti N. E. Brown. Revista Brasileira de Fruticultura, v. 28, n. 2, p. 267-270, 2006. http://dx.doi.org/10.1590/S0100-29452006000200025

FERREIRA, D. F. Sisvar: a computer statistical analysis system. Ciência e Agrotecnologia, v. 35, n. 6, p. 1039-1042, 2011. http://dx.doi.org/10.1590/S1413-70542011000600001 
FREITAS, S. J.; CARVALHO, A. J. C.; BERILLI, S. S.; SANTOS, P. C.; MARINHO, C. S. Substratos e osmocote $^{\circledR}$ na nutrição e desenvolvimento de mudas micropropagadas de abacaxizeiro cv. Vitória. Revista Brasileira de Fruticultura, v. 33, n. 1, p. 672-679, 2011. http://dx.doi.org/10.1590/S010029452011000500094

GALDIANO-JUNIOR, R. F.; MANTOVANI, C.; PIVETTA, K. F. L.; LEMOS, E. G. M. Crescimento in vitro e aclimatização de Cattleya loddigesii Lindley (Orchidaceae) com carvão ativado sob dois espectros luminosos. Ciência Rural, v. 42, n. 5, p. 801-807, 2012. http://dx.doi.org/10.1590/S0103-84782012005000019

KNAPIK, J. G.; ANGELO, A. C. Pó de basalto e esterco equino na produção de mudas de Prunus sellowii Koehne (Rosaceae). Floresta, v. 37, n. 3, p. 427-436, 2007. http://dx.doi.org/10.5380/rf.v37i3.9939 LEMOS, E. E. P.; FERREIRA, M.S.; ALENCAR, L. M. C.; RAMALHO-NETO, C. E.; ALBUQUERQUE, M. M. Conservação in vitro de germoplasma de cana-de-açúcar. Pesquisa Agropecuária Brasileira, v.37, n.10, p.1359-1364, 2002. http://dx.doi.org/10.1590/S0100-204X2002001000002

LOPEZ-PUC, G. An effective in vitro slow growth protocol for conservation of the orchid Epidendrum chlorocorymbos SCHLTR. Tropical and Subtropical Agroecosystems, v. 16, p. 61-68, 2013.

MARCO-MEDINA, A.; CASAS, J. L. Polyamine content during minimal growth storage of Thymus moroderi explants. Biologia Plantarum, v. 56, n. 3, p. 590-594, 2012. http://dx.doi.org/ 10.1007/s10535-012-0061-y

MONTEIRO, S. H. N.; CARREGOSA, T.; SANTOS, L. A. S.; NASCIMENTO JUNIOR, J. E.; PRATA, A. P. N. Survey of Orchidaceae from the State of Sergipe, Brazil. Biota Neotropica, v. 12, n. 2, p. 167-174, 2012. http://dx.doi.org/10.1590/S1676-06032012000200016

MOREIRA, B. M. T.; TOMBA, E. C.; ZONETTI, P. C. Crescimento in vitro de plântulas de orquídea (Laelia purpurata lindl var venosa x Cattleya warneri t. moore alba) sob diferentes concentrações de sacarose e frutose. Revista de Saúde e Biologia, v. 2, n. 2, p. 16-21, 2007.

NG, C. Y.; SALEH, N. M. In vitro propagation of Paphiopedilum orchid through formation of protocorm-like bodies. Plant Cell Tiss Organ Cult, v. 105, p. 193-202, 2011. http://dx.doi.org/10.1007/s11240-010-9851-0

PEIXOTO, M. G.; OLIVEIRA, A. C. L.; BLANK, A. F.; SILVA, J. H. S.; LUZ, J. M. Q,; ARRIGONIBLANK, M. F. In vitro conservation and leaf anatomy of different chemotypes of Lippia alba (Mill.) N. E. BR. Bioscience Journal, v. 33, n. 1, p. 41-51, 2017. http://dx.doi.org/10.14393/BJ-v33n1a2017-35757

POSPÍSILOVÁ, J.; SYNKOVÁ, H.; HAISEL, D.; SEMORÁDOVÁ, S. Acclimation of plantlets to ex vitro conditions: effects of air humidity, irradiance, $\mathrm{CO}_{2}$ concentration and abscisic acid. Acta Horticulturae, v. 748, p. 29-38, 2007. http://dx.doi.org/10.17660/ActaHortic.2007.748.2

RECH, A. R.; ROSA, Y. B. C. J.; ROSA-JUNIOR, E. J. Levantamento e características ecológicas de Orchidaceae da mata ciliar do Rio Dourados, Dourados-MS. Revista Arvore, v. 35, n. 3, p. 717-724, 2011. http://dx.doi.org/10.1590/S0100-67622011000400016

ROBERTS, D. L.; DIXON, K. W. Orchids. Current Biology, v. 18, p. 325-329, 2008. http://dx.doi.org/10.1016/j.cub.2008.02.026

ROCHA, E. L. J.; CARVALHO, A. C. P. P.; AZEVEDO, B.M.; MARINHO, A. B.; VIANA, T. V. A.; VASCONCELOS, D. V. Aclimatização de mudas micropropagadas de helicônia em ambiente protegido em função do tipo de substrato. Ciência e Agrotecnologia, v. 33, n. 6, p. 1457-1462, 2009.

http://dx.doi.org/10.1590/S1413-70542009000600001

SANTA-ROSA, S.; SOUZA, F. V. D.; VIDAL, Á. M.; LEDO, C. A. S.; SANTANA, J. R. F. Micropropagation of the ornamental vulnerable bromeliads Aechmea blanchetiana and Aechmea distichantha. Horticultura Brasileira, v. 31, n. 1, p. 112-118, 2013. http://dx.doi.org/10.1590/S0102-05362013000100018 
SANTOS, T. C.; ARRIGONI-BLANK, M. F.; BLANK, A. F.; MENEZES, M. M. L. A.; Conservação in vitro de acessos de vetiver, Chrysopogon zizanioides (L.) ROBERTY (Poaceae). Bioscience Journal, v. 28, n. 6, p. 963-970, 2012.

SILVA, A. B.; PASQUAL, M.; MACIEL, A. L. R.; DUTRA, L. F. BAP e substratos na aclimatização de plântulas de glioxinía (Sonningia speciosa Lood. Hiern.) proveniente de cultura de tecidos. Ciência e Agrotecnologia, v. 27, n. 2, p. 255-260, 2003. http://dx.doi.org/10.1590/S1413-70542003000200002

UENO, S.; Diversidade e estrutura genética de população de Oeceoclades maculata (Lindl.) Lindl. 2013. 76f. Dissertação (Mestrado em Ciências) - Curso de Pós-Graduação em Ciências, Universidade de São Paulo, São Paulo-SP, 2013. http://dx.doi.org/10.11606/D.11.2013.tde-22082013-161459 